US agricultural research criticized

\section{White House demands more project grants}

\section{Washington}

A shake-up in the pattern of agricultural research in the United States may yet materialize. A group of agricultural experts assembled by the White House has urged a substantial expansion of competitive agricultural research grants, now consuming only $\$ 16$ million out of the $\$ 1,500$ million spent by the US Department of Agriculture (USDA) on research each year. The group says that under the present system, agricultural research is not always of the highest quality or focused on the most critical problems.

Although not new, the group's recommendation may carry more weight than earlier pleas on behalf of USDA's fragile competitive grants programme, for it included representatives of those who have most opposed the programme - the landgrant colleges and the state agricultural experiment stations. Traditionally these have seen competitive funding as a threat to their "formula funds", doled out on a state-by-state scheme dating back to 1887 .

Dennis Prager, the assistant director of the White House Office of Science and Technology Policy who organized the group, says that "the agriculture research community has not kept pace with the cutting-edge of basic science"'. Institutions

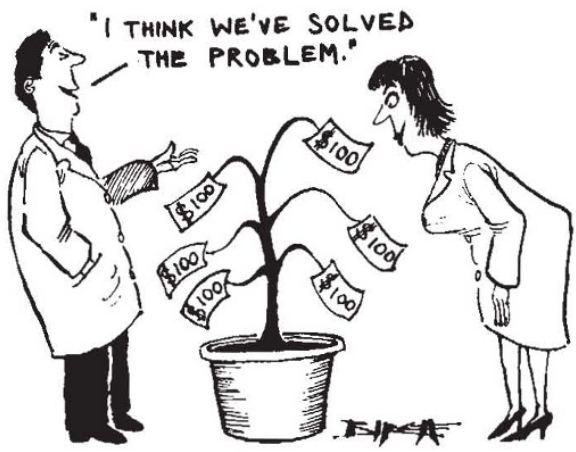

such as Harvard and Stanford Universities, which are not in the land-grant college system, find it almost impossible to obtain research support from USDA. The establishment of the department's competitive grants programme in 1978 changed that picture only slightly. One conseqence, according to Prager, is that "the really exciting basic biological science is going on outside the agricultural system".

Lawrence Bogorad of Harvard University, a plant biologist, argues that while there is expertise within the USDA system, those outside who could contribute something to agriculture are put off by the difficulty of obtaining funding: "If you're in something that's really medically related, you can get reasonably funded with one or two grants. The problem with the plant business is that you get a little here and a little there. You spend more time writing applications." Or, you go into another field: "It's a good time now for young people trained in molecular biology to go into the plant sciences. But their question is invariably, will I get money to do this?"'

Ralph Hardy, director of life sciences at Dupont and a participant in the White House study, points to plant growth regulators as an example of past underinvestment in the plant sciences. Dupont is interested in increasing yields by reducing the wasteful oxygen reaction in plant photorespiratory systems (so increasing the plant's utilization of carbon dioxide, and thus increasing photosynthesis); but, says Hardy, "the problem is that our base of information has not been adequate" to develop a growth regulator that would accomplish this.

A perennial obstacle to would-be reformers of the agricultural research system is the sensitivities of those within. Despite the pains that the study took to underline the importance of retaining the present formula-funding for the land-grant colleges and state experiment stations. Prager has reportedly been the object of an intense campaign to have him fired.

The recent appointment of Orville Bentley, dean of the agricultural school at the University of Illinois, as the new assistant secretary for science and education at USDA is considered a good sign by those advocating change. Terry Kinney, director of USDA's Agricultural

\title{
Clinch River saved temporarily
}

\section{Washington}

The fates of two important technical projects, the Landsat satellite system and the Clinch River fast reactor, will now be decided by the lame-duck session of Congress that assembles after the elections on 2 November. That is the effect of the stop-gap spending bill passed hurriedly last week by Congress so as to avoid bringing government business to a halt on 1 October, the beginning of the new financial year. The stop-gap measure, known as a continuing resolution, will allow the Administration to keep on spending at the present rate only until 15 December.

Opponents of the reactor will try again when Congress returns after the elections to deal with the unfinished appropriations bills. They point out that in last week's Senate vote, three senators were absent who are all on record as opposing Clinch River. That would give the opponents a two-vote margin. And in the House, opponents believe that the only thing that stopped them this time was a rule forbidding floor amendments to continuing bills; an amendment to delete funding for Clinch River is thus almost certain to come up in the lame-duck session.

Meanwhile, the Department of Energy (DoE) began site preparation for the reactor after an injunction was lifted by the Federal Court of Appeals in Atlanta. This had been granted by a lower court to environmental groups, which had charged DoE with failing to obtain the proper water permits before beginning construction. DoE appears anxious to make as much progress as possible with the project before another vote comes up in Congress.

The lame-duck Congress will also have the task of straightening out funding for Landsat, which nearly became the victim of budgetary shuffling in last week's con- tinuing resolution. Operation of Landsat D (launched on 16 July of this year) is due to transfer from the National Aeronautics and Space Administration (NASA) to the National Oceanic and Atmospheric Administration (NOAA) in January 1983. But by late September, Congress had not passed any authorization for the transfer, and the House Appropriations Committee accordingly deleted the $\$ 15$ million requested for NOAA's operation of Landsat from the appropriations bill for the 1983 fiscal year.

The House version of the continuing resolution followed suit, holding NOAA's spending for Landsat at the 1982 rate of only $\$ 1.4$ million per year. NOAA of ficials were alarmed; if the new money was not authorized by 15 October, they would not be able to award a contract for operation and maintenance in time to allow for a smooth transition and training of new personnel. The Senate, however, included the higher figure in their version and, luckily for Landsat, prevailed when the two versions were reconciled.

Just before Congress adjourned, a House-Senate conference committee cleared the way for a permanent resolution of the muddle by agreeing on language for a NASA authorization bill which includes the transfer of operating authority over Landsat to NOAA.

The conference committee also agreed to defer a decision on whether to transfer Landsat ultimately to the private sector, a goal of the Reagan Administration. The bill orders the Department of Commerce (of which NOAA is a part) to study alternatives such as a phased transfer; the creation of a corporation along the lines of COMSAT, which operates communications satellites; and keeping the present arrangement. 